Barbara Strzałkowska

UKSW, Warszawa

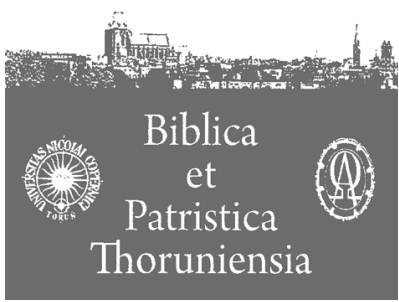

$4(2011)$

ISSN 1689-5150

\title{
Księga Rodzaju w Septuagincie
}

\section{The Book of Genesis in the Septuagint}

Słowa klucze: Księga Rodzaju, Septuaginta, Grecka Biblia, techniki translacyjne w Septuagincie, starożytne wersje Starego Testamentu, Rdz 1, Rdz 4.

Key words: Book of Genesis, Septuagint, Greek Bible, Septuagint of Genesis, translation technique in the Septuagint, ancient versions of the Old Testament, Gen 1, Gen 4.

$\mathrm{K}^{\mathrm{s}}$ sięga Rodzaju, pierwsza księga Pięcioksięgu i całego Starego Testamentu, według wszelkich danych, została także w Biblii Greckiej przełożona na samym początku, jako pierwsza spośród wszystkich ksiąg Biblii Hebrajskiej ${ }^{1}$.

1 Zapewne z tego powodu na temat Księgi Rodzaju w LXX powstało wiele opracowań. Obok fragmentów w ogólnych opracowaniach dot. Septuaginty, pierwsze większe opracowanie Rdz w LXX powstało na początku XX w.: J. Hänel, Die außermasorethischen Übereinstimmungen zwischen der Septuaginta und der Peschittha in der Genesis, „Beihefte zur Zeitschrift für die alttestamentliche Wissenschaft" (BZAW) 20, Giessen 1911. Kolejne opracowania są już bardziej współczesne: J. W. Wevers, Text History of the Greek Genesis, „Mitteilungen des Septuaginta-Unternehmens der Akademie der Wissenschaften in Göttingen” 11 (Abhandlungen der Akademie der Wissenschaften in Göttingen 81), Göttingen 1974; tenże, Notes on the Greek Text of Genesis, „Septuagint and Cognate Studies” 35, Atlanta, Georgia 1993; M. Harl, La Bible d'Alexandrie I: La Genèse. Traduction du texte grec de la Septante, Introduction et Notes, Éditions du CERF, Paris 1986, 1994²; M. Rösel, Übersetzung als Vollendung der Auslegung. Studien zur Genesis-Septuaginta, Beihefte zur Zeitschrift für die alttestamentliche Wissenschaft (BZAW) 223, Berlin, New York 1994 (oraz tenże, Abstract aus: Übersetzung als Vollendung der Auslegung Studien zur Genesis-Septuaginta, „Bulletin of the International Organization for Septuagint and Cognate Studies” 28/1995, s. 42-50). Zob. także szereg artykułów o charakterze ogólnym na temat Rdz w LXX, np.: J. Cook, The Translator of the Greek Genesis, w: La Septuaginta en la investigación contemporánea (V Congreso de la IOSCS), red. N. Fernández Marcos, Madrid 1985, s. 169-182; tenże, The Exegesis of the Greek Genesis, w: VI Congress of the International Organization for Septuagint and Cognate Studies, red. tenże, Atlanta, Georgia 1987, s. 91-125; tenże, The Septuagint of Genesis: Text and/or Interpretation?, w: Studies in the Book of Genesis, red. 
W tym sensie znaczenie jej greckiego przekładu jest wyjątkowe - stanowić może bowiem w jakimś sensie wzór i odniesienie dla pozostałych przekładów ksiąg hebrajskich w LXX². Można na grecką Księgę Rodzaju (LXXRdz) spojrzeć jak na programowy przekład dla całej Septuaginty, opierając sie na nim, można dostrzec problemy, z którymi borykali się wszyscy tłumacze ksiąg LXX. Chodzi o dylematy, których pięknym wyrazem mogą być słowa jednego z tych

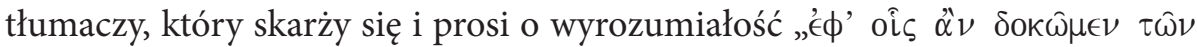

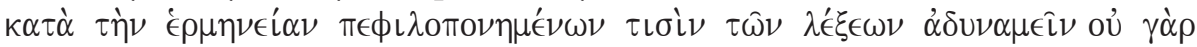

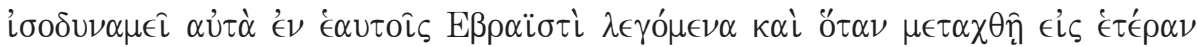
$\gamma \lambda \omega \sigma \sigma \alpha \alpha \nu^{\prime \prime}$ („w tych [miejscach], gdzie jak się wydaje, mimo usilnej pracy nad tłumaczeniem nie wszystkie wyrażenia udało się oddać, gdyż nie mają tej samej mocy słowa w języku hebrajskim, co przełożone na inny język"; Prolog do Księgi Syracydesa 19-22).

Szczególnego znaczenia nabiera w tym kontekście także fakt, że LXXRdz to najstarszy przekład tekstu hebrajskiego Księgi Rodzaju, jaki posiadamy. Wszystkie inne tradycje językowe tej Księgi są późniejsze. Dlatego też przyjrzenie się temu dawnemu przekładowi pomoże ukazać także, w jakim kierunku szła interpretacja tej ważnej części spuścizny biblijnego Izraela (jej ważnych tekstów dotyczących początków świata, człowieka i narodu izraelskiego) w czasach, kiedy kanon Pisma Świętego był jeszcze in statu fieri, dopiero się kształtował.

\section{Datacja pierwotnego przekładu greckiego Rdz (Old Greek)}

Księga Rodzaju w LXX powstała w kilka wieków później niż jej hebrajski oryginał. Powstała także w innym środowisku - jest owocem diaspory żydowskiej posługującej się językiem greckim, żyjącej w Aleksandrii okresu hellenistycz-

A. Wénin, Bibliotheca Ephemeridum Theologicarum Lovaniensium 155, Leuven 2001, s. 315-329; F. W. Knobloch, "Transcription Technique» and the Text of the Greek Genesis, "Bulletin of the International Organization for Septuagint and Cognate Studies” 35/2002, s. 97-109; R. J. V. Hiebert, The Hermeneutics of Translation in the Septuagint of Genesis, w: Septuagint Research, red. W. Kraus, Atlanta, Georgia 2006, s. 85-103.

$\mathrm{Na}$ gruncie polskim są jedynie dwa opracowania podejmujące kwestię $\mathrm{Rdz}$ w LXX; najnowsze: K. P. Kowalik, Reinterpretacja tekstu o Abrahamie w Rdz 11,27-25,18 w Septuagincie, Series Biblica Paulina 8, Częstochowa 2010; oraz nieco starsze: S. Gądecki, Związek między Septuagintą a targumami na przykładzie Księgi Rodzaju, „Studia Gnesnensia” 8/1984-1985, s. 109-130.

2 Taką tezę we współczesnych badaniach wysunął np. E. Tov (The Impact of the LXX Translation of the Pentateuch on the Translation of the Other Books, w: Mélanges Dominique Barthélemy. Études bibliques offertes à l'occasion de son 60e anniversaire, red. P. Casetti, Orbis Biblicus et Orientalis 38, Fribourg, Göttingen 1981, s. 577-591). 
nego ${ }^{3}$. Właśnie w tym środowisku, od III w. przed Chr. podjęto się przekładu ksiąg hebrajskich na język grecki. Według wszelkiego prawdopodobieństwa pierwszą przełożoną księgą byłą Księga Rodzaju. A cały przekład grecki zyskał miano Septuaginty ${ }^{4}$. O początkach i dziejach tego przekładu mówi legenda zawarta w Liście Pseudo-Arysteasza, mówiąca o powstaniu greckiego przekładu Tory (w tym także Księgi Rodzaju) za panowania Ptolemeusza II Filadelfa (285-247 przed Chr.) $)^{5}$. Przekład powstać miał na życzenie tego władcy, chcącego umieścić w bibliotece Aleksandryjskiej, największej bibliotece ówczesnego świata, teksty różnych społeczności zamieszkujących hellenistyczny Egipt. Potwierdzają tę wersję powstania LXX także inne pisma starożytne: Arystobula, Filona z Aleksandrii i Józefa Flawiusza ${ }^{6}$.

Również współczesne badania nad powstaniem przekładu LXX potwierdzają, że pogląd prezentowany w tych źródłach starożytnych, datujący LXX

3 Na temat dziejów powstania LXX zob. choćby: G. Dorival, Les origines de la Septante: la traduction en grec des cinq livres de la Torah, w: La Bible Grecque des Septante. Du judaïsme hellénistique au christianisme ancien, G. Dorival, M. Harl, O. Munnich, Initiations au christianisme ancien, Paris 1988, s. 39-82; N. Fernández Marcos, The Origins of the Septuagint, w: tenże, The Septuagint in Context. Introduction to the Greek Version of the Bible, Boston, Leiden 2000, s. 35-105; K. Jobes, M. Silva, The Origin of the Septuagint and Other Greek Versions, w: Invitation to the Septuagint, Grand Rapids MI 2000, s. 29-44; S. Jellicoe, Septuagint Origins and Transmission-History, w: tenże, The Septuagint and Modern Studies, Oxford 1968, s. 29-171 i wiele innych opracowań. W tym co dotyczy LXXRdz zob. M. Rösel, The Text-Critical Value of Septuagint-Genesis, „Bulletin of the International Organization for Septuagint and Cognate Studies” 31/1998, s. 63-64.

4 Pierwotnie terminu „Septuaginta” używano w wąskim znaczeniu, jako przekład Tory (w tym także Rdz). Dopiero z czasem przyjął on szersze znaczenie: najpierw oznaczając wszystkie księgi Biblii Hebrajskiej, które przetłumaczono na język grecki, a z czasem przyjmując jeszcze szersze znaczenie - Biblia Grecka par excellance, zawierającą przekłady wszystkich ksiąg Biblii Hebrajskiej (w tym Tory), ale także księgi, które powstały, zostały spisane, bądź zachowały się w języku greckim.

5 Na ten temat Listu Pseudo-Arysteasza, powstała bardzo bogata literatura. Por. na jego temat (w kontekście powstania przekładu LXX): B. Strzałkowska, Ksiegga Kapłańska w Septuagincie, „Collectanea Theologica” 80 (2010)4, s. 69-72. Por. także tekst krytyczny Listu Pseudo-Arysteasza, w opracowaniu H. S. J. Thackereya w: H. B. Swete, An Introduction to the Old Testament in Greek, Cambridge $1914^{2}$, s. 533-606. Tekst ten wydany został także osobno: H. S. J. Thackerey, W. O. E. Oesterley, G. H. Box, The Letter of Aristeas: Translated with an Appendix of Ancient Evidence on the Origin of the Septuagint, Translations of Early Documents 2, London-New York 1917. W języku polskim jej przekład i komentarz wraz z bogatą bibliografią przedmiotu zob.: M. Wojciechowski, List Pseudo-Arysteasza, „Studia Theologica Varsaviensia" 40 (2002)1, s. 121-167.

6 Por. G. Dorival, Les origines de la Septante: la traduction en grec des cinq livres de la Torah, s. 45-50. 
(w tym także LXXRdz) na III przed Chr. nie jest pozbawiony podstaw. Oczywiście wiadomo obecnie, że proces ten trwał dłużej niż opisywane w Liście Pseudo-Arysteasza 72 dni, a większość egzegetów ukazuje tekst całej LXX jako owoc pracy wielu pokoleń aleksandryjskich tłumaczy ${ }^{7}$. Także w tym co dotyczy poszczególnych ksiąg, które miałyby być owocem tego złożonego procesu, którego dzieje, próbuje się odtworzyć w badaniach krytyczno-tekstualnych.

Księga Rodzaju w tych badaniach jest wyjątkowo uprzywilejowana. $\mathrm{Na}$ temat jej tekstu i wersji powstało wiele opracowań, dlatego też i jej datacja, wydaje się sprawą mniej złożoną niż w przypadku pozostałych ksiąg. Także tekst LXXRdz jest na tyle spójny, że do minimum ograniczone są debaty, czy przekładał ją jeden, czy też wielu tłumaczy ${ }^{8}$, co zdarzało się przy innych księgach. To wszystko pozwala na dość jednolitą datację tego przekładu na III w. przed Chr., a nawet, jak czyni to np. M. Rösel, na dokładne jego datowanie na ok. 247 r. przed Chr. ${ }^{9}$, albo, jak czynili to inni, na 281 r. przed Chr. (np. N. L. Collins ${ }^{10}$ ).

Niezwykle istotny $\mathrm{w}$ badaniach nad wiekiem oraz zwłaszcza tekstem LXXRdz jest fakt, że nie posiadamy żadnego fragmentu oryginalnego tekstu, który wyszedłby spod pióra samego tłumacza LXX, tak jak nie posiadamy rękopisów hebrajskich spod pióra natchnionego autora ${ }^{11}$. Dlatego ten pierwotny

7 Streszczenie tych poglądów zob. B. Strzałkowska, Księga Kapłańska w Septuagincie, s. $69-72$.

8 Teoria według której LXXRdz miała być przełożona przez dwóch tłumaczy pojawiła się w dawniejszej literaturze dot. LXXRdz, ale potem podejmowano ją z niezwykłą ostrożnością, albo wcale. Por. choćby: O. J. Baab, The Theory of Two Translators for the Greek Genesis, „Journal of Biblical Literature” 52/1933, s. 239-243.

9 Taka datacja wiąże się z konkretną interpretacją Rdz 2,14; por. M. Rösel, Übersetzung als Vollendung der Auslegung. Studien zur Genesis-Septuaginta, s. 66; a także tenże, The Text-Critical Value of Septuagint-Genesis, s. 63.

10 N. L. Collins, 281 BC - the Year of the Translation of the Pentateuch into Greek under Ptolemy II, w: Septuagint, Scrolls and Cognate Writings, red. G. J. Brooke, B. Lindars, „SBL Septuagint and Cognate Studies" 33, Atlanta, Georgia 1992, s. 403-503.

11 O ile jednak w przypadku tekstu hebrajskiego przyzwyczailiśmy się do badań krytycznych nad historią jego powstania, w przypadku ksiąg greckich wciąż panuje przekonanie o jednolitości tego tekstu, a problematyka złożonych dziejów jego powstania jest stosunkowo nowa, opracowywana dopiero od kilkudziesięciu lat. Tymczasem tak jak musimy docierać do pierwotnego tekstu hebrajskiego, choć nie posiadamy manuskrytpu spod pióra autora natchnionego, tak musimy też starać się docierać do pierwotnego tekstu greckiego i to zagadnienie krytyki tekstualnej, różnych recenzji i wersji LXX jest współcześnie jednym z poważniejszych wyzwań badaczy LXX. Ponieważ tekst LXX jest złożony, toteż krytyka tekstualna LXX stanowi dziś jedno z najtrudniejszych, a zarazem najważniejszych wyzwań stojących przed badaczami tekstu Starego Testamentu. 
tekst tłumaczenia LXXRdz, nazywany czasem w obszarze języka angielskiego Old Greek, próbuje się odtwarzać na podstawie rozmaitych przesłanek, przede wszystkim na podstawie posiadanych manuskryptów oraz wersji tekstu.

\section{Manuskrypty i kodeksy LXXRdz. Wydania krytyczne}

Choć potrafimy dość precyzyjnie określić datę powstania przekładu LXXRdz, to jednak niemal pełny grecki tekst Księgi Rodzaju, jaki posiadamy pochodzi dopiero z przełomu IV i V w. po Chr., zatem ponad 500 lat po samym przekładzie. Tekst ten pochodzi z Kodeksów Aleksandryjskiego z V w. po Chr. (zwłaszcza dobrze zachowane, z drobnymi korektami, są tam rozdz. $1-46,28)^{12}$ oraz z Kodeksu Watykańskiego z przełomu IV i V w. (gdzie zachowała się część także 46,28-50) ${ }^{13}$. Rozdziały 23,19-24,6 z kolei bardzo dobrze zachowały się także w Kodeksie Synaickim, najstarszym z greckich dużych kodeksów jakie mamy (z IV w. po Chr.) ${ }^{14}$ : fragmenty te zachowały się jako część jedynego arkuszu tekstu LXXRdz w tym kodeksie ${ }^{15}$. J. W. Wevers wylicza jeszcze inne fragmenty kodeksów majuskułowych $z$ tekstem LXXRdz - chodzi o: Kodeks D (zwany Cottonianus ${ }^{16}$, z przełomu V i VI w. po Chr., obecnie w Londynie, zawierający liczne, ale niewielkie fragmenty LXXRdz), Kodeks F (zwany Ambrosianus ${ }^{17}$, z V w po Chr. ${ }^{18}$, obecnie w Mediolanie, zawierający większe partie tekstu LXXRdz), Kodeks G (zwany Colberto-Sarravianus z przełomu IV i V w. po Chr., obecnie w Leiden, zawierający fragment Rdz 31,53-36,18), Kodeks L (zwany Purpureus Vindobodensis ${ }^{19}$, z przełomu V i VI w. po Chr., obecnie w Wiedniu) oraz Kodeks M (zwany Coislinianus,

12 Por. Septuaginta. Vetus Testamentum Graecum. Auctoritate Academiae Scientiarum Gottingensis editum, t. I: Genesis, red. J. W. Wevers, Göttingen 1974, s. 9.

13 Tamże.

14 Tamże, s. 12-13.

15 J. W. Wevers powołuje się w swoich uwagach dot. tekstu LXXRdz na opracowanie Kodeksu Synaickiego dokonane w dziele C. Tischendorf, Monumenta sacra inedita, Nova collectio 2, Leipzig 1857.

16 Za: The Old Testament in Greek. Volume I, The Octateuch. Part I, Genesis: Acoording to the text of Codex Vaticanus, Supplemented from Other Uncial Manuscripts, with a Critical Apparatus Containing the Variants of the Chief Ancient Authorities for the Text of the Septuagint, red. A. E. Brooke, n. Mclean, Cambridge 1906, s. V.

\footnotetext{
17 Tamże.

18 U A.E. Brooke’a znajdujemy jego datację na VII w po Chr. Por. tamże.

19 Tamże.
} 
z VII w po Chr. ${ }^{20}$, obecnie w Bibliotece Narodowej w Paryżu ${ }^{21}$. Liczba kodeksów majuskułowych z tekstem LXXRdz jest zatem imponująca jednocześnie zwraca uwagę fakt, że kodeksy te, zwłaszcza w przypadku początkowych rozdziałów Rdz są dość zniszczone i wytarte - co spowodowane jest faktem, iż znajdowały się na samym ich początku.

Tekst LXXRdz odtwarza się dziś w oparciu właśnie o te kodeksy, a także o kilkadziesiąt fragmentów manuskryptów minuskułowych i innych niesklasyfikowanych rękopisów ${ }^{22}$, a także na podstawie ponad trzydziestu papirusów ${ }^{23}$, zawierających mniejsze lub większe fragmenty LXXRdz. W odtworzeniu tego tekstu pomocne są też inne wersje językowe oraz cytaty zawarte w pismach Ojców Kościoła (także stosunkowo liczne) i inne przytoczenia Rdz w pismach starożytnych.

Wszystkie te teksty pomagają dotrzeć do hipotetycznego tekstu greckiej Księgi Rodzaju, najbliższego możliwie pierwotnemu jej brzemieniu, które wyszło spod pióra tłumacza (Old Greek). Na ich podstawie także wydano kilka wydań krytycznych LXXRdz. Pod względem krytycznych opracowań grecka Księga Rodzaju pozostaje jedną z najlepiej reprezentowanych. Najważniejszym i najdokładniejszym obecnie wydaniem krytycznym LXXRdz jest tzw. Septuagina z Göttingen, w której Księga Rodzaju wydana została już w 1974 jako pierwsza spośród wszystkich ksiąg LXX (jej redaktorem był J.W. Wevers $)^{24}$. Ten sam redaktor jest także autorem najobszerniejszych opracowań tekstu LXX Rdz ${ }^{25}$.

Obok niego są jeszcze dawniejsze opracowania całościowe LXX, zawierające tekst LXXRdz, wśród nich: opracowanie A. E. Brooke’a z początku XX wieku ${ }^{26}$,

20 U A. E. Brooke’a znajdujemy jego datację na X w po Chr. Por. Tamże.

21 Septuaginta. Vetus Testamentum Graecum, t. I Genesis, red. J. W. Wevers, s. 10-12.

22 Tamże, s. 13-22.

23 Tamże, s. 22.

24 Już cytowana: Septuaginta. Vetus Testamentum Graecum. Auctoritate Academiae Scientiarum Gottingensis editum, t. I: Genesis, red. J. W. Wevers, Göttingen 1974.

25 Choćby w książkach: J. W. Wevers, Text History of the Greek Genesis, Göttingen 1974; tenże, Notes on the Greek Text of Genesis, Atlanta, Georgia 1993 (obie już cytowane).

26 Już cytowana: The Old Testament in Greek. Volume I, The Octateuch. Part I, Genesis: Acoording to the text of Codex Vaticanus, Supplemented from Other Uncial Manuscripts, with a Critical Apparatus Containing the Variants of the Chief Ancient Authorities for the Text of the Septuagint, red. A. E. Brooke, N. Mclean, Cambridge 1906. 
ostatnio wznowione ${ }^{27}$, a także wydania całej LXX A. Rahlfsa ${ }^{28}$ oraz dawniejsze, ale bardzo cenione wydanie B. W. Swetego ${ }^{29} \mathrm{i}$ inne, jeszcze starsze, opracowania zawierające bezcenne noty o różnych wariantach i lekcjach ${ }^{30}$. Dla pełnego obrazu tekstu LXX konieczna jest także konsultacja z wydaniem Hexapli Orygenesa opracowanej przez F. Fielda ${ }^{31}$.

Jakie znamy najstarsze świadectwa tekstu LXXRdz? W przeciwieństwie do Księgi Liczb, Kapłańskiej czy Powtórzonego Prawa, które zostały odnalezione w 4 grocie w Qumran i są najstarszymi świadkami greckiego tekstu tych ksiąg $^{32}$, nie mamy w Qumran przykładu choćby fragmentu greckiej Księgi Rodzaju (choć pojawiają się jej manuskrypty hebrajskie). Nie znaczy to jednak, że w Qumran ich nie było. Obecność greckich tekstów Kpł, czy Lb świadczy, że Tora i to przełożona na język grecki była znana w Qumran, była zatem znana w środowisku palestyńskim (nie tylko zaś aleksandryjskim, w którym powstała $)^{33}$. Datuje się je na II i I w. przed Chr., zatem jedynie 100-200 lat po powstaniu przekładu ${ }^{34}$.

Najstarszy znany fragment greckiej Księgi Rodzaju pochodzi także z tego okresu, z I w. przed Chr., dokładnie z ok. 50 r. przed Chr. i został odnaleziony w Kairze. Nosi numer 942, inaczej nazywa się go także papirusem Fouad ${ }^{35}$. Zawiera on bardzo fragmentaryczne części LXXRdz z 7,17-20 oraz 38,10-12.

27 The Old Testament in Greek: According to the Text of Codex Vaticanus, Supplemented from Other Uncial Manuscripts, with a Critical Apparatus Containing the Variants of the Chief Ancient Authorities for the Text of the Septuagint. Volume 1, red. A. E. Brooke, N. Mclean, Cambridge Library Collection, Cambridge-New York-Melbourne 2009.

28 Septuainta. Id est Vetus Testamentum graece iuxta LXX interpretes, red. A. Rahlfs, Stuttgart $1979^{2}$.

29 The Old Testament in Greek According to the Septuagint, t. I: Genesis-IV Kings, red. H. B. Swete, Cambridge 1901.

30 Wspomina o nich: H. B. Swete, Printed Texts of the Septuagint, w: tenże, An Introduction to the Old Testament in Greek, Cambridge 1914 (wyd. drugie), s. 171-194. Por. także komentarz: M. A. Zipor, Some Notes on the Greek Text of Genesis in the Common Editions, Bulletin of the International Organization for Septuagint and Cognate Studies 35/2002, s. 121-126.

31 F. Field, Origenis Hexaplorum que supresunt; sive veterum interpretum graecorum in totum Vetus Testamentum fragmenta, t. I: Genesis, Oxford 1875, s. 1-74.

32 O tych tekstach w przypadku Kpł zob. B. Strzałkowska, Księga Kapłańska w Septuagincie, s. 74-76.

33 Tamże, s. 75.

34 Tamże, s. 75-76.

35 Na jego temat zob. F. Dunand, Extrait des Etudes de papyrology, t. IX, Caire 1966, s. 81-82. Por. Septuaginta. Vetus Testamentum Graecum, t. I: Genesis, red. J. W. Wevers, s. 25. 
Inne dawne manuskrypty LXXRdz to pochodzący z I w. po Chr. Papirus 814, datowany na ok. 90 r. po $\mathrm{Chr}^{36}$ Zawiera on niepełny tekst greckich fragmentów Rdz 14,5-8.12-15.

Pozostali świadkowie tekstu są już późniejsi: jak pochodzący z III w. po Chr. papirus Oxyrynhos, numerowany przez J. W. Weversa jako 905 i 907 oraz $944^{37}$ oraz inny papirus z III w. po Chr, noszący numer $911^{38}$, a zawierający sporą liczbę tekstów LXXRdz. Oraz papirus o numerze 995, również z III w. po Chr., zawierający kilka fragmentów wersetów z greckiej Rdz $19^{39}$.

Fragmenty te potwierdzają zasadniczo tekst grecki Rdz jaki znamy z późniejszych kodeksów majuskułowych. Zatem trzeba przyznać, że starożytni dołożyli wszelkich starań, by zachować i przekazać następnym pokoleniom zasadniczo wierny tekst LXXRdz, bliski najprawdopodobniej temu, który wyszedł spod pióra starożytnego tłumacza w Aleksandrii.

W odtworzeniu tego pierwotnego tekstu LXXRdz pomocne są także starożytne przekłady Rdz dokonane za LXX i zależne od niej. Wśród najważniejszych jest przekład koptyjski ${ }^{40}$. Potwierdza on zasadniczo wersję LXX i jest jej dosłownym przekładem. Inne zależności, np. $\mathrm{z}$ wersją arabską ${ }^{41}$, także pomagają w odtworzeniu greckiego tekstu.

\section{Charakter przekładu LXXRdz - dosłowność czy „niewolnicza” wierność?}

To, co trzeba podkreślić na samym początku, to fakt, że tłumacze LXXRdz dołożyli wszelkich starań, by oddać jej hebrajski pierwowzór jak najwierniej.

Zob. także: O. Munnich, Le texte de la Septante, w: La Bible Grecque des Septante. Du judaïsme hellénistique au christianisme ancien, s. 132.

36 Septuaginta. Vetus Testamentum Graecum, t. I Genesis, red. J. W. Wevers, s. 22. Por. także: J. F. Oates, A. E. Samuel, C. B. Welles, Yale Papyri in the Beinecke Rare Book and Manuscript Library I, New Haven-Toronto 1967, s. 3-8.

37 Septuaginta. Vetus Testamentum Graecum, t. I Genesis, red. J. W. Wevers, s. 23-25.

38 Tamże, s. 24.

39 Tamże, s. 28.

40 Przekład ten oraz jego opracowanie zob. A Critical Edition of the Coptic (Bohairic) Pentateuch. Volume 1: Genesis, red. M. K. H. Peters, Septuagint and Cognate Studies 19, Atlanta, Georgia 1985; tenże, The Textual Affinities of the Coptic (Bohairic) Version of Genesis, w: VI Congress of the International Organization for Septuagint and Cognate Studies, red. C. E. Cox, s. 233-254.

41 Por. J. W. Wevers, The Arabic Versions of Genesis and the Septuagint, „Bulletin of the International Organization for Septuagint and Cognate Studies” 3/1970, s. 8-11. 
Niewiele jest przykładów ksiąg w LXX, które charakteryzowałaby się aż taką starannością. „Ogólna ocena greckiej Księgi Rodzaju jest taka, że leksykalnie i syntaktycznie jest ona ścisłym i dokładnym odpowiednikiem jej tekstu źródłowego" ${ }^{42}$. Przekład LXXRdz prezentuje duży poziom zależności od tekstu hebrajskiego, zarówno jeśli chodzi o język, oddanie treści, jak i o strukturę Księgi. Chyba nie ma drugiej tak dokładnie przełożonej Księgi w LXX jak Rdz (może jeszcze podobny poziom zachowany został przy pozostałych księgach Tory). Nie ma w LXXRdz problemów charakterystycznych dla późniejszych ksiąg LXX: dla Księgi Hioba, czy Przysłów, czy też Ksiąg Jeremiasza i Samuela, które przedstawiają wiele zmian ${ }^{43}$ : Księga Hioba jest w LXX krótsza o 1/5 od Tekstu Masoreckiego, Księga Jeremiasza jest krótsza o ok. 1/8; dodatkowo obie księgi zawierają wiele zmian w tekście przełożonym; w Księdze Jeremiasza oraz w Księdze Przysłów poprzesuwane są rozdziały względem siebie, a w Księdze Hioba mamy także charakterystyczne dla tekstu LXX dodatki ${ }^{44}$. W przypadku Księgi Rodzaju aż tak radykalnych problemów nie ma. Zasadniczo przełożono ją bardzo wiernie. Wydaje się, że tłumaczowi (tłumaczom) chodziło, by jak najlepiej i jak najdokładniej przekazać tę część swojej spuścizny, która pod wieloma względami była najważniejsza.

Zarzucano nawet przekładowi Rdz w LXX, że jest zbyt niewolniczo wierny hebrajskiemu tekstowi (R. J. V. Hiebert używa takiego określenia jak slavishly subservient to the Hebrew ${ }^{45}$ ). I poniekąd tak jest, ale nie do końca.

Po pierwsze, „grecki tekst Księgi Rodzaju bez wątpienia oddaje strukturę swojego hebrajskiego pierwowzoru"46. Podział Księgi Rodzaju obecny w TM, tradycyjnie dzielący ją na dwie części: Rdz 1,1-11,26 (mówiącej o „historii początkow”, „pradziejach biblijnych”, „prehistorii biblijnej”, czy „historii pierwotnej" - niem. Urgeschichte, o początkach świata i człowieka); oraz Rdz 11,27-50,26 (przedstawiającej historię Abrama-Abrahama, „dzieje patriarchów” od rodowodu Abrama aż do śmierci Józefa, czy inaczej mówiąc „początki Izra-

42 R. J. V. Hiebert, Genesis. To the Reader, w: A New English Translation of the Septuagint. And the Other Greek Translations Traditionally Included under that Title (NETS), red. A. Pietersma, B. G. Wright, New York-Oxford 2007, s. 1.

43 J. Cook wysnuwa taką konkluzję po dokładnych procentowych wyliczeniach zmian w LXXRdz i w innych księgach; por. J. Cook, The Exegesis of the Greek Genesis, s. 98-100.

44 Na ten temat por. B. Strzałkowska, Mowy Elihu (Hi 32-37) oraz ich reinterpretacja w Biblii Greckiej, Rozprawy i Studia Biblijne 35, Warszawa 2009.

45 R. J. V. Hiebert, Genesis. To the Reader, w: NETS, s. 1.

46 M. Harl, La Bible d'Alexandrie I: La Genèse, s. 31. 
ela"), pozostaje dokładnie taki sam w LXXRdz ${ }^{47}$, przy czym obie części tworzą spójną i logiczną całośćc ${ }^{4}$.

Taki podział wynika z treści Księgi Rodzaju. Dodatkowo można ją także wyraźnie podzielić - analogicznie do tego, jak czyniono to także z tekstem hebrajskim - na poszczególne sedery, jednostki czytań synagogalnych, praktykowanych we wspólnotach żydowskich starożytnej Aleksandrii ${ }^{49}$. Taki podział miał dotyczyć całej Tory, i jego poświadczona obecność w LXX może świadczyć także o charakterze przekładu LXX (także LXXRdz), który służyć miał konkretnym potrzebom konkretnej wspólnoty. Wprawdzie najstarsze posiadane manuskrypty nie posiadają w ogóle podziału w tekście, a z kolei manuskrypty majuskułowe, na bazie których powstawały wydania krytyczne LXXRdz, dzielą tekst już według chrześcijańskiego sposobu jego czytania, to jednak można dotrzeć do podziałów na sedery w manuskryptach minuskułowych ${ }^{50}$. Według badaczy, owych sederów w LXXRdz było 46, a te wyznaczone były na 12 części roku liturgicznego ${ }^{51}$.

Po drugie, obok wspomnianego podziału treści Księgi, także w samym tekście LXXRdz możemy spotkać przykłady niezwykłej - wręcz „niewolniczej” dosłowności w odniesieniu do hebrajskiego oryginału tekstu.

Przykładem mogą być te wyrażenia, które zostały tak dokładnie i dosłownie przełożone $\mathrm{z}$ języka hebrajskiego, że aż tracą sens na gruncie języka greckiego. Kilka przypadków w LXXRdz może być dobrym tego przykładem, który przy okazji ukazuje nie tylko wielką staranność tłumaczenia, w którym tłumacz nie chciał, by cokolwiek umknęło z wymowy hebrajskiego tekstu, ale ukazuje także, że tłumacz, przekładając tekst na język grecki, niejako myślał wciąż po hebrajsku. Jednym z ciekawszych przykładów obrazujących ten problem może być tekst Rdz 11,10, gdzie jest m.in. mowa o latach życia Sema. Tekst hebrajski

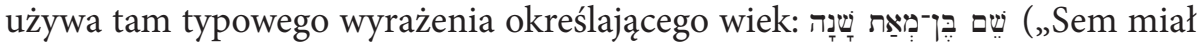
sto lat”; dosł. „Sem [był] synem stu lat”). Tłumacz grecki przełożył to wyrażenie, które jedynie na gruncie języka hebrajskiego miało sens, przez dosłowne

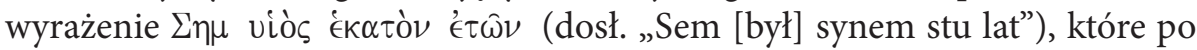
grecku brzmiało nielogicznie ${ }^{52}$.

Podobny przypadek można znaleźć w Rdz 9,5, gdzie idiomatyczne wyraże-

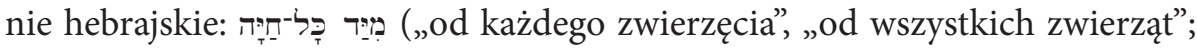

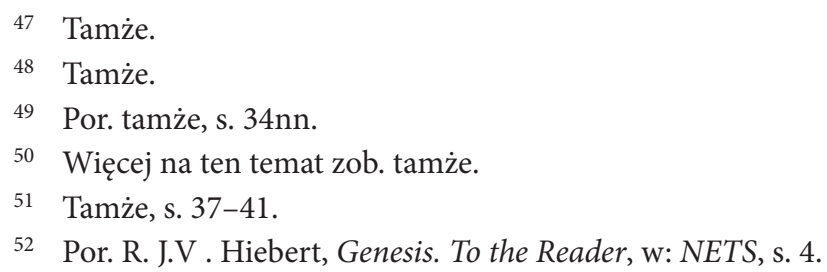




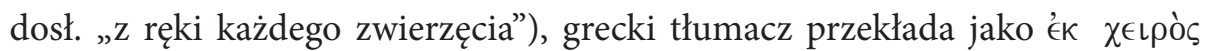

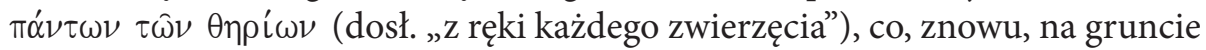
języka greckiego nie brzmiało sensownie ${ }^{53}$.

Tego typu zmiany nazywa się czasem hebraizmami, a ich przykłady (także mniej radykalne) w LXXRdz można mnożyć ${ }^{54}$. Występują jeszcze np. w: 4,2.8; 12,$19 ; 24,12 ; 33,19^{55}$, a także w 20,$13 ; 24,41 ; 44,21$ i inne ${ }^{56}$. Zasadniczo dzieli się je na takie, które nie mają wcześniejszego zastosowania w języku greckim i są prostymi kalkami hebrajskiego tekstu (przykłady powyższe), albo też takie, które są obecne w literaturze greckiej poprzedzającej LXX, ale w LXX występują zdecydowanie częściej ${ }^{57}$.

Dokładność tłumacza greckiego Rdz przejawia się także niekiedy w stosowaniu transkrypcji w miejscach, gdzie uznał to za stosowne, a czasem nawet tam, gdzie nie ma takiej konieczności ${ }^{58}$. Np. w tekście 3,24 nie tłumaczy on

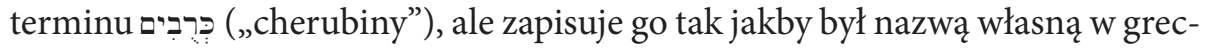
kim alfabecie jako: $\chi \epsilon \rho o u ß \iota \mu$, pozostawiając hebrajską formę mnogą, a także obecny w tekście hebrajskim rodzajnik ${ }^{59}$. Co ciekawe, termin ten użyty przez tłumacza Rdz stał się w LXX terminem technicznym na określenie cherubinów wszędzie tam, gdzie występowały (znakomita większość w Księdze Wyjścia).

Tłumacz grecki Rdz stosował transkrypcję także w przypadku imion i nazw własnych - chodzi o nazwy miejscowości i inne nazwy geograficzne, a także o nazwy np. roślin, jak w 22,13. W tym ostatnim przypadku zresztą tłumacz użył transkrypcji, gdyż - jak się wydaje - nie był pewien znaczenia występującego w zdaniu terminu hebrajskiego oְב („zarośla”, „chaszcze”) ${ }^{60}$. Termin ten w prostej transkrypcji brzmi "sebak”, natomiast tłumacz grecki, nie znając znaczenia tego terminu, a domyślając się, że chodzi o jakąś roślinę w swoim prze-

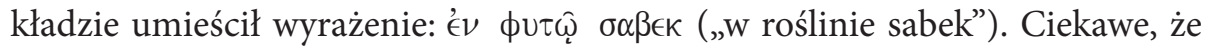
ten termin (właściwie transkrypcja) występuje w całej LXX tylko tu. Ciekawe także, że tłumacz grecki inaczej zwokalizował hebrajski termin niż wskazuje na to masorecka wokalizacja - zamiast „sebak”, jego transkrypcja brzmi „sabek”.

53 Por. tamże, s. 3.

54 Na ten temat wraz z licznymi przykładami zob. H. S. Gehman, Hebraisms of the Old Greek Version of Genesis, „Vetus Testamentum” 3/1953, s. 141-148.

55 R. J. V. Hiebert, Genesis. To the Reader, w: NETS, s. 3-4.

56 Por. H. S. Gehman, Hebraisms of the Old Greek Version of Genesis, s. 141-147.

57 Por. R. J. V. Hiebert, Genesis. To the Reader, w: NETS, s. 3.

58 Na temat stosowanej przez tłumacza LXXRdz transkrypcji zob. F. W. Knobloch, "Transcription Technique» and the Text of the Greek Genesis, s. 97-109.

59 Por. R. J. V. Hiebert, Genesis. To the Reader, w: NETS, s. 3.

60 Por. tamże. 
Te i inne przykłady ${ }^{61}$ mogą stanowić zobrazowanie wspomnianej „niewolniczej” wierności tekstowi oryginalnemu. Mimo to są one w całej Księdze liczącej 50 rozdziałów jednak marginalne. W greckim przekładzie Rdz w LXX mamy do czynienia z przekładem wiernym i dokładnym, czasem dosłownym, a ciekawe jest to, że zdarzają się w nim także pewne korekty i drobne zmiany tłumacza (które omówione zostaną w dalszej części artykułu). Tłumaczenie Księgi Rodzaju w LXX (tak jak i innych ksiąg LXX) powstało jednak w innym czasie i środowisku niż hebrajski oryginał, co z pewnością musiało wywrzeć wpływ na sam przekład i jego charakter. Przekład ten musiał także oddać specyfikę hebrajskiego sposobu mówienia po grecku, który to język ma zupełnie inny charakter: tłumacz przekładał z języka semickiego na niesemicki, a mimo to starał się oddać jak najwierniej tekst i jego treść. Stąd też zmian i problemów dotyczących LXXRdz jest niemało. W przypadku Księgi Rodzaju tym bardziej warto się im przyjrzeć, ponieważ, jako najdawniejsze tłumaczenie księgi hebrajskiej, w jakimś sensie wyznaczy ono szlaki, którymi szli następnie wszyscy tłumacze LXX. Znaczenie zarazem tych zmian i ich charakter ukażą także kierunki w jakich szła interpretacja tych ważnych tekstów zawartych $\mathrm{w}$ Rdz. $\mathrm{W}$ tym sensie LXX przestaje być postrzegana jedynie w perspektywie narzędzia pomocnego przy krytyce tekstu hebrajskiego (choć to także ${ }^{62}$ ), ale staje się odrębną i ważną tradycją ${ }^{63}$.

Spośród kilku charakterystycznych cech przekładu greckiego Księgi Rodzaju, zostaną omówione najbardziej znaczące przykłady.

\section{Tytuł Księgi Rodzaju w LXX}

Pierwszym, co rzuca się w oczy przy lekturze greckiej wersji Księgi Rodzaju, jest fakt, że tłumacze LXX nadali poszczególnym księgom - także Rdz - tytuły

61 Więcej przykładów zob. F. W. Knobloch, «Transcription Technique» and the Text of the Greek Genesis, s. 100-108.

62 Na temat znaczenia tekstu LXX dla odtworzenia tekstu hebrajskiego Księgi Rodzaju zob. debatę: M. Rösel, The Text-Critical Value of Septuagint-Genesis, „Bulletin of the International Organization for Septuagint and Cognate Studies" 31/1998, s. 62-70; W. P. Brown, Reassessing the Text-Critical Value of Septuagint-Genesis 1: A Response to Martin Rösel, "Bulletin of the International Organization for Septuagint and Cognate Studies” 32/1999, s. 35-39; R. S. Hendel, On the Text-Critical Value of Septuagint Genesis: A Reply to Rösel, Bulletin of the International Organization for Septuagint and Cognate Studies 32/1999, s. 31-34.

63 Por. na ten temat także K. P. Kowalik, Reinterpretacja tekstu o Abrahamie $w$ Rdz 11,27-25,18w Septuagincie, s. 235. 
inne niż czyniła to tradycja hebrajska. W tradycji hebrajskiej tytuły te brały się od pierwszych słów ksiąg. W tradycji greckiej zaś - zgodnie z ich tematem centralnym ${ }^{64}$. I tak tematem drugiej Księgi Pięcioksięgu było wyjście Izraelitów

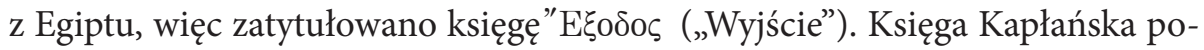
święcona była kultowi i w jakimś stopniu kapłanom, których identyfikowano z lewitami, stąd też tytuł trzeciej Księgi Tory w tradycji greckiej brzmi $\Lambda \epsilon \cup \ddot{\imath} \tau \hat{i}$ кòv. Podobnie zgodnie z treścią Księgi nadano tytuł Księdze Rodzaju: hebraj-

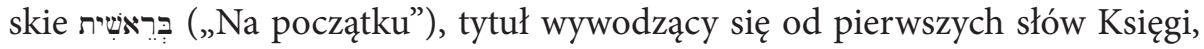

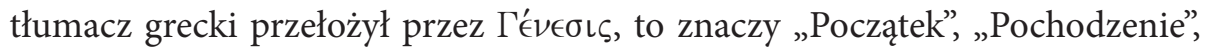

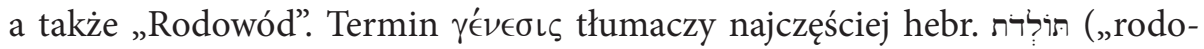
wód”), charakterystyczny dla tej części Pięcioksięgu, która wylicza wiele list imion poszczególnych pokoleń, potomków poszczególnych bohaterów. Ale nie tylko o imiona tu chodzi ${ }^{65}$ (o czym zaraz).

Tytuł $\Gamma^{\prime} \in \in \sigma \iota \varsigma$ pojawia się po raz pierwszy w kodeksie Bedlaianus Geneseos (E), datowanym na przełom IX i X w. po Chr. ${ }^{66}$ oraz w Kodeksie Coislinianus (M) z VII w. po Chr. ${ }^{67}$, a także w niektórych kodeksach minuskułowych.

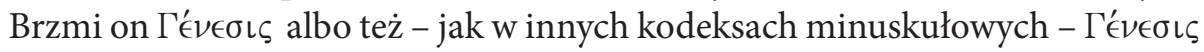
$\beta \iota \beta \lambda$ íov. Ciekawy tytuł nadaje mu Kodeks Aleksandryjski, który zawiera in-

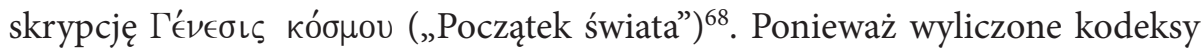
są stosunkowo późne można zastanawiać się, czy sam tytuł także nie został nadany późno. Jednak poświadczają go także wcześniejsze źródła: pojawia się on już w pismach Filona Aleksandryjskiego, a później także w Księdze Jubileuszów we fragmencie greckim 2,169. Warto podkreślić, że Filon Aleksandryjski, który podaje taki tytuł pierwszej księgi Tory, był zarazem jednym z pierwszych komentatorów jej greckiej wersji.

Tytuł ten odzwierciedla rozumienie i interpretację Księgi Rodzaju, którą tradycja grecka postrzegała jako „Księgę Początku”, „Księgę Pochodzenia” czy inaczej „Księgę Rodowodu”, co byłoby tłumaczeniem hebrajskiego תוֹלְ.

Taki tytuł może być nawiązaniem do obecnej w Rdz 2,4 oraz 5,1 formuły:

64 Na ten temat zob. M. Harl, La Bible d'Alexandrie I: La Genèse, s. 31-32; G. Dorival, La traduction en grec des cinq livres de la Torah, s. 65-66.

65 Na temat terminu i jego konotacji w greckim tekście Księgi Rodzaju zob. K. P. Kowalik, Reinterpretacja tekstu o Abrahamie w Rdz 11,27-25,18 w Septuagincie, s. 404-405.

66 The Old Testament in Greek According to the Septuagint, t. I: Genesis-IV Kings, red. H. B. Swete, s. XXVI oraz 1.

67 Septuaginta. Vetus Testamentum Graecum, t. I Genesis, red. J. W. Wevers, s. 75.

68 Tamże.

69 M. Harl, La Bible d’Alexandrie I: La Genèse, s. 32. 


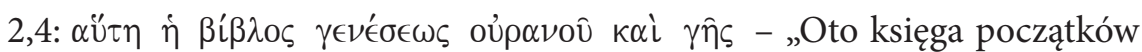
(pochodzeń) nieba i ziemi"

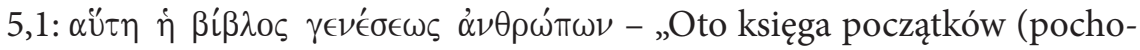
dzeń) ludzi (w liczbie mnogiej!)”. Co ciekawe w tekście tym pojawia się inter-

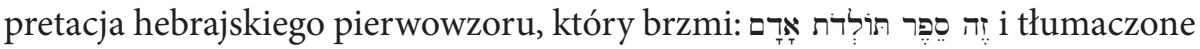
jest najczęściej (np. w Biblii Tysiąclecia) z imieniem własnym: „Oto rodowód potomków Adama”. Tłumacz grecki zdecydował się przełożyć termin hebrajski אָד jako „człowiek” i to w liczbie mnogiej, co nadało temu tekstowi wymiar bardziej uniwersalny, a zarazem podkreślił w całej księdze jej znaczenie: jako mówiącej o początkach nieba i ziemi (to znaczy świata) oraz ludzi ${ }^{70}$.

Wspomniana zmiana z 5,1, zwraca uwagę, że w Rdz nie chodzi tylko o Adama, ale także o początki w wielu sensach: początki świata, początki ludzkości, początki narodu Izraela, początki wybrania, początki Bożego działania w swoim ludzie. Tradycja grecka, nadając pierwszej Księdze Tory nowy tytuł, wskazała zarazem na jej interpretację.

W LXXRdz jeszcze trzykrotnie pojawi się termin $\gamma^{\prime} \cup \in \sigma \iota \varsigma, \mathrm{z}$ czego 2 razy w tekście mówiącym o „ziemi Twoich początków” $(31,13 ; 32,10)$, co także ukazuje nowe horyzonty interpretacji: początek to nie tylko naród, ale i ziemia początków tego narodu.

Warto zauważyć, że w polskiej tradycji tytuł Księgi nawiązuje właśnie do tej tradycji greckiej, która przez tekst łaciński przeszła do języka polskiego i została upowszechniona jako Księga Rodzaju za sprawą Biblii Jakuba Wujka. Coraz częściej także proponuje się tytuł „Księga Początków”71, który jeszcze wyraźniej do tej greckiej tradycji nawiązuje.

\section{Inne cechy przekładu LXXRdz - niektóre typy zmian}

Oprócz zmienionego w LXX tytułu są jeszcze inne cechy charakterystyczne dla greckiego przekładu Księgi Rodzaju, zmienione względem hebrajskiego pier-

70 Ciekawe, że w greckiej Księdze Rodzaju w tym samym zdaniu mamy także pewną

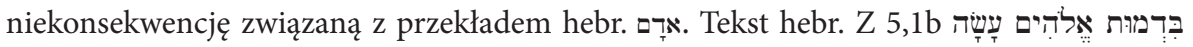
- „Gdy Bóg stwarzał człowieka (także „Adama”), na podobieństwo Boga stworzył go”, w tekście greckim przełożony został odwrotnie względem 5,1a, miano-

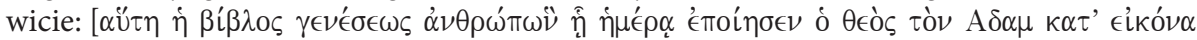

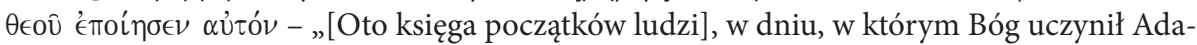
ma (imię własne!), na podobieństwo Boga go uczynił”. Ta niekonsekwencja każe się nam zastanowić nad jej znaczeniem i interpretacją.

71 Np. na ten temat dawny artykuł: T. B., Genesis - księga początków, „Znaki Czasu” 40 (1962)1, s. 12-13. 
wowzoru. Wspomniana wcześniej zgodność z tekstem hebrajskim nie oznacza bowiem, że nie mamy o czym mówić w przypadku tego przekładu. Według znanej zasady, według której tłumacz (traduttore) jest często zdrajcą (traditore), w każdym przekładzie, nawet najwierniejszym, znajdą się pewne świadome bądź nie przeróbki i zmiany - które są wyrazem wspomnianych dylematów tłumaczy świętych ksiąg ${ }^{72}$. Nie jest więc prawdą, że żadnych zmian w Księdze Rodzaju w LXX względem hebrajskiego oryginału nie ma! Zmiany są! I to dość liczne i ciekawe. W przypadku Kpł w LXX zmian było aż ok. 600 w całej Księdze złożonej z 27 rozdziałów (średnio po 20 wersetów każdy, musiałoby być po kilka zmian w wersecie ${ }^{73}$. Tu - ze względu na objętość Księgi - zmian może być nawet więcej, jeśli weźmiemy pod uwagę także te drobne, gramatyczne (np. spójnikowe) przeróbki itd. ${ }^{74}$

72 O tych dylematach na przykładzie Księgi Rodzaju, a także o tym, jak dziś należy „przekładać przekład”, zwłaszcza w kontekście najnowszego całościowego tłumaczenia LXX, jaki posiadamy - NETS (A New English Translation of the Septuagint, red. A. Pietersma, B. G. Wright, New York-Oxford 2007), zob. R. J. V. Hiebert, Translation Technique in the Septuagint of Genesis and Its Implications for the NETS Version, „Bulletin of the International Organization for Septuagint and Cognate Studies" 33/2000, s. 76-93; tenże, Translating a Translation: The Septuagint of Genesis and the NETS Project, $\mathrm{w}$ : X Congress of the International Organization for Septuagint and Cognate Studies, Oslo, 1998, red. B. A. Taylor, Atlanta, Georgia 2001, s. 263-284; tenże, Ruminations on Translating the Septuagint of Genesis in the Light of the NETS Project, w: "Translation Is Required»: the Septuagint in Retrospect and Prospect, red. tenże, Atlanta, Georgia 2010, s. 71-86. O przykładzie innych ksiąg i na temat charakteru i techniki przekładu stosowanych przez tłumaczy LXX, zob. także jedną z najnowszych publikacji: Translating a Translation. The LXX and Its Modern Translations In the Context of Early Judaism, red. H. Ausloos, J. Cook, F. García Martínez, B. Lemmelijn, M. Vervenne, Bibliotheca Ephemeridum Theologicarum Lovaniensium 213, Leuven 2008; a także: S. Olofsson, God Is My Rock. A Study of Translation Technique and Theological Exegesis in the Septuagint, Coniectanea Biblica - Old Testament Series 31, Stockholm 1990; A. Aejmelaeus, On the Trail of the Septuagint Translators. Collected Essays, Kampen 1993; J. A. Beck, Translators as Storytellers. A Study in Septuagint Translation Technique, "Studies in Biblical Literature" 25, New York (i inne) 2000; R. David, M. Jinbachian, Traduire la Bible Hébraïque. De la Septante à la Nouvelle Bible Segond. Translating the Hebrew Bible. From the Septuagint to the Nouvelle Bible Segond, Sciences Bibliques 15, Montréal 2005; A. Léonas, Recherches sur la langage de la Septante, Orbis Biblicus et Orientalis 211, Göttingen, 2005; J. Cook, Translating a Translation: Some Methodological Considerations on the Translation of the Septuagint, w: XII Congress of the International Organization for Septuagint and Cognate Studies, Leiden 2004, red. M. K. H. Peters, "SBL Septuagint Research" 54, Atlanta 2006, s. 29-40; T. Van Der Louw, Approaches in Translation Studies and Their Use for the Study of the Septuagint, w: tamże, s. 17-28.

73 Por. B. Strzałkowska, Księga Kapłańska w Septuagincie, s. 78.

74 Wylicza je procentowo J. Cook (The Exegesis of the Greek Genesis, s. 98-100). 
Zmiany w LXXRdz badacze dzielą zwyczajowo na kilka grup (podział ten oczywiście nie jest ścisły, niektóre ze zmian śmiało można zaliczyć do kilku grup jednocześnie).

\section{Zmiany formalne, gramatyczne i leksykalne}

Pierwszą z nich są zmiany formalne: różne wariacje redakcyjne i stylistyczne ułatwiające czytanie go po grecku, czy drobne zmiany gramatyczne, dotyczące zmiany z jednego języka na drugi, które to zmiany, choć najliczniejsze, nie zostaną omówione w tym artykule, ponieważ nie mają aż tak wielkiego znaczenia dla interpretacji tego tekstu jak pozostałe typy zmian ${ }^{75}$.

Inne zmiany dotyczą stosowanej w przekładzie LXX terminologiii ${ }^{76}$. W Rdz LXX pojawia się ok. 50 terminów nieznanych w szerokiej greckiej literaturze ${ }^{77}$. Większość z nich to stworzone przez tłumacza neologizmy, powstałe ze znanych słów greckich z dodaniem prefiksów lub sufiksów. Umiejętność tworzenia neologizmów świadczy o kreatywności tłumacza (tłumaczy) Księgi. Dobrym przykładem może być użyty w Rdz 48,10 jedyny raz występujący w LXX termin

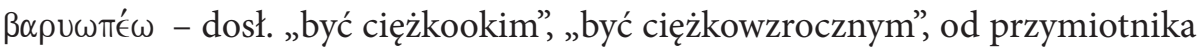

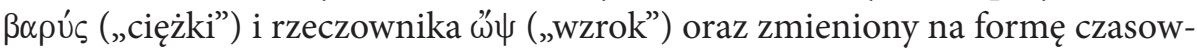
nikową. Termin ten w kontekście wersetu tłumaczy hebrajskie wyrażenie z po-

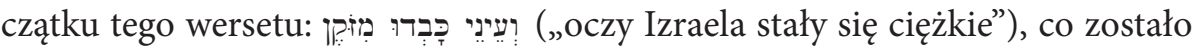

75 Na temat pewnych gramatycznych niuansów LXXRdz powstało kilka opracowań, por. np.: T. P. Scher, The Perfect Indicative in Septuagint Genesis, „Bulletin of the International Organization for Septuagint and Cognate Studies” 24/1991, s. 14-24; R. Sollamo, Repetitions of Prepositions in the Septuagint of Genesis, w: Interpreting Translation, red. F. García Martínez, Leuven 2005, s. 371-384. Por. także K. P. Kowalik, Zmiany gramatyczne i drobne uzupetnienia oraz nietypowe zastosowanie przysłówków w TG, w: tenże, Reinterpretacja tekstu o Abrahamie w Rdz 11,27-25,18 w Septuagincie, s. 262-265 oraz s. 243-247.

76 Na temat terminologii LXXRdz zob. najnowsze opracowanie: Septuagint Vocabulary: Pre-history, Usage, Reception, red. J. Joosten, E. Bons, „SBL Septuagint and Cognate Studies" 58, Atlanta, Georgia 2011. Por. także: A. L. Lee, A Lexical Study of the Septuagint Version of the Pentateuch, „SBL Septuagint and Cognate Studies Series” 14, Chico 1983; E. Tov, Studies in the Vocabulary of the Septuagint. The Relation Between Vocabulary and Translation Technique, Tarbiz 47/1978, s. 120-138; tenże, The Impact of the LXX Translation of the Pentateuch on the Translation of the Other Books, w: Mélanges Dominique Barthélemy. Études bibliques offertes à l'occasion de son 60e anniversaire, red. P. Casetti, Orbis Biblicus et Orientalis 38, Fribourg, Göttingen 1981, s. 577-591.

77 R. J. V. Hiebert, Genesis. To the Reader, w: NETS, s. 2-3. 


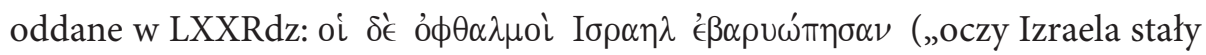
się ciężkookie (ciężkowzroczne)"] ${ }^{78}$.

Inny przykład neologizmu to stworzony przez tłumacza czasownik Łं $\nu \tau \alpha \phi i ́ \alpha \zeta \omega$ („owinąć w całun”, dosł. „Zacałunować) z Rdz 50,2, gdzie występuje dwukrotnie. Został on utworzony z rzeczownika ' $€ \tau \tau \alpha \phi i ́ o \nu$ („całun”) i nigdzie poza tym wersetem nie występuje ani w LXX, ani poza nią ${ }^{79}$.

\section{Zmiany harmonizujące i/ lub doprecyzowujące (zarazem interpretujące tekst)}

Oprócz poziomu terminologii i gramatyki, a także innych zmian formalnych tłumacz LXX niektóre teksty Rdz starał się zmienić, doprecyzować i zharmonizować lub dostosować do czytelnika żyjącego w innym środowisku niż to, w którym powstał tekst hebrajski. Zmiany te mogą dotyczyć wielu sytuacji, począwszy od nazw geograficznych, niezrozumiałych w innym kontekście, a skończywszy na zwyczajach, światopoglądzie czy zawiłościach teologicznych. W przypadku Księgi Rodzaju nie ma wielu tego typu zmian, jednak można takie przykłady znaleźć.

Do najbardziej rzucających się w oczy przykładów należą zmiany precyzujące, np. z rozdz. 7,2-3, który mówi o zwierzętach nieczystych, które mają być wprowadzone do arki Noego. Tekst hebrajski mówi najpierw o czystych zwierzętach, a następnie o nieczystych, samcu i samicy w w. 2b:

משן ze zwierząt zaś nieczystych, po jednej parze, samca i samicę"). W w. 3 mówi z kolei o ptakach, analogicznie do zwierząt: najpierw o czystych, ale nie nazywa ptaków z drugiej części zdania „nieczystymi”. Tekst grecki przez analogię do poprzedniego wersetu doprecyzowuje, iż w w. 3, że

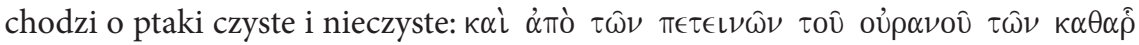

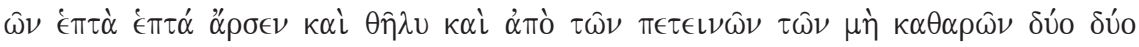

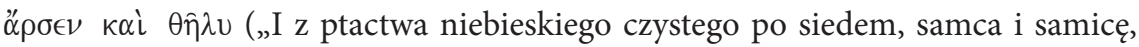
a z ptactwa nie nieczystego, po dwie, samca i samicę"), czego nie doprecyzował tekst hebrajski. Tego typu doprecyzowujące i harmonizujące zmiany są typowe dla przekładu LXX ${ }^{80}$.

\footnotetext{
78 Ten i inne przykłady zob. tamże, s. 2.

79 Por. tamże.

80 Na ich temat w Księdze Rodzaju wraz z konkretnymi przykładami, zob.: K. P. Kowalik, Precyzowanie elementów opisywanych wydarzeń oraz Harmonizacja tekstu, w: tenże, Reinterpretacja tekstu o Abrahamie $w$ Rdz 11,27-25,18 w Septuagincie, s. 247-255 oraz s. 341-392.
} 
Również kolejna zmiana będzie miała właśnie taki charakter - dotyczy ona czasu trwania potopu, gdzie znów w LXXRdz 7,17 znajduje się doprecyzowanie. W kontekście poprzedzającym ten werset, na początku w. 7,12 w tekście hebrajskim jest mowa o tym, że potop trwał „czterdzieści dni i czterdzieści

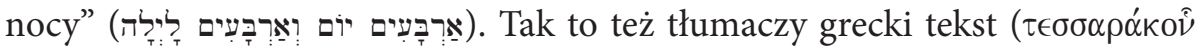

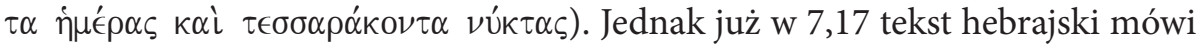
tylko o czterdziestu dniach, nie wspominając o nocach, jednak tłumacz grecki chcąc ujednolicić tekst, dodał konsekwentnie wyrażenie „i czterdzieści nocy”

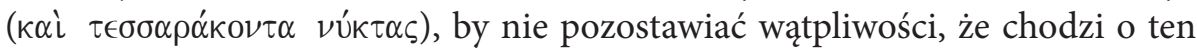
sam czas i o to samo wydarzenie.

Podobne zmiany można znaleźć w Rdz 17,14, gdzie mowa o obrzezaniu ${ }^{81}$; 18,10 , gdzie mowa o narodzinach syna ${ }^{82} ; 18,16$ przy nazwach Sodomy i Gomory ${ }^{83}$; i w innych miejscach.

Zmiany o charakterze doprecyzowującym i harmonizującym są obecne także w chyba najbardziej znanym tekście Księgi Rodzaju - opowiadaniu o stworzeniu świata i człowieka ${ }^{84}$. W tekście hebrajskim tego opowiadania mamy wyliczone stworzenie ośmiu dzieł w sześć dni, a hymn ten ma charakterystyczną strukturę z wielokrotnie powtarzanymi zwrotami. Do takich zwro-

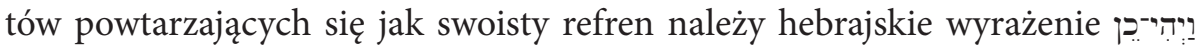
(„,i stało się tak”), które w tej lub trochę zmienionej formie pojawia się w omawianym tekście wielokrotnie (1,7.9.11.15.24.30 lub trochę zmienione w: 1,3; 2,7), jako wyraz potwierdzający nastanie rzeczywistości stwarzanej przez Boga. Nie przy wszystkich jednak wersetach to potwierdzenie się pojawia. Nie ma go np. w w. 1,6, ale w tym miejscu tradycja grecka dokona harmonizacji tego tekstu, dodając brakujący element struktury w tekście hebrajskim:

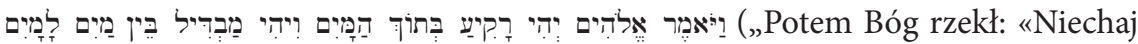
powstanie sklepienie w środku wód i niechaj ono będzie oddzieleniem między jed-

81 K. P. Kowalik, Precyzowanie elementów opisywanych wydarzeń, s. 248-249.

82 Tamże, s. 249-250.

83 Tamże, s. 250-251.

84 Na temat tego tekstu powstała wielka liczba publikacji. W Polsce ostatnio np. opracowania w: Genesis 1-3. Tekst, interpretacje, przemyślenia, red. Z. Pawłowski, „Scripta Theologica Thoruniensia" 4, Torun 2009. Na temat LXXRdz w tym co dot. pierwszych rozdziałów Księgi, zob. np. J. Cook, Genesis I in the Septuagint as Example of the Problem: Text and Tradition, „Journal of Northwest Semitic Languages” 10/1982, s. 25-36; tenże, The Septuagint of Genesis: Text and/or Interpretation?, w: Studies in the Book of Genesis, red. A. Wénin, Leuven 2001, s. 317-321; tenże, The Exegesis of the Greek Genesis, s. 101-113 ; por. także: G. L. Prato, Lantropologia riduttiva dei LXX in Genesi 1-11, „Annali di Scienze Religiose" 4/1999, s. 131-155. 
nymi a drugimi wodami»”), a tłumacz grecki dodaje ten „refren”, który był obecny

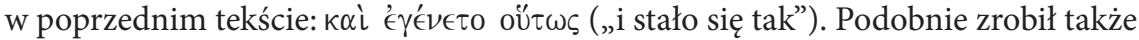
w 1,20 .

Ciekawa zmiana $\mathrm{w}$ opowiadaniu o stworzeniu dot. także wersetu 1,9 (w kontekście ww. 9-10), gdzie mamy w tekście hebrajskim tekst:

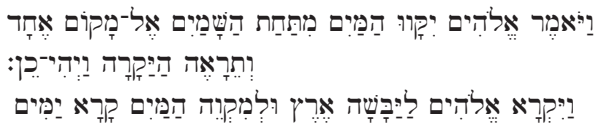

Potem Bóg rzekł: «Niechaj zbiorą się wody spod nieba w jedno miejsce i niech się ukaże powierzchnia sucha!». I tak się stało. I nazwał Bóg powierzchnię suchą ziemią, a zbiorowisko wód nazwał morzem.

Tłumacz grecki do tekstu Bożego rozkazu z w. 9 dodał jego wypełnienie, dokładnie wzorowane na słowach rozkazu; tekst ten w LXXRdz brzmi:

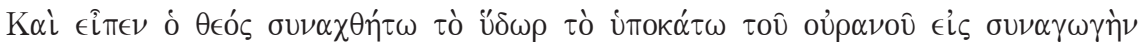

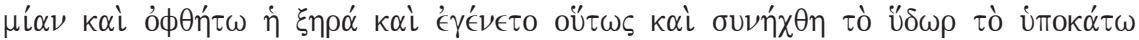

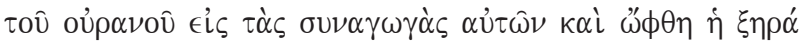

„I rzekł Bóg: «niechaj zbiorą się wody podniebne w jedno miejsce i ukaże się powierzchnia sucha!» I stało się tak. I zebrały się wody podniebne w jedno miejsce i było widać powierzchnię suchą".

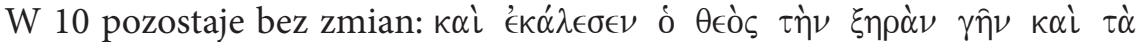

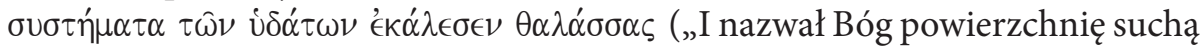
ziemią, a zebranie wód nazwał morzem").

Te zmiany doprecyzowujące czy harmonizujące, choć wydają się czysto techniczne, mają za zadanie uporządkowanie tekstu, który tłumaczowi wydawał się niekonsekwentny lub za mało uporządkowany. Kiedy tłumacz wyczuł, że może gdzieś ten rytm tekstu hebrajskiego jest zakłócony - zmieniał go. Zatem $\mathrm{w}$ jakimś sensie interpretował także tekst.

Najbardziej znaną zmianą, ukazującą, że tłumacz LXXRdz wraz z harmonizacją dodał do tekstu swoje jego rozumienie, pojawia się tekście mówiącym o historii Kaina i Abla z rozdz. 4,1-8. Zmiana ta pozwala nie tylko zrozumieć niejasny w tym miejscu tekst hebrajski (LXX będzie w tym przypadku podstawowym odniesieniem dla krytyki tekstu hebrajskiego), ale także ukazać rolę tłumacza LXX, który harmonizując tekst nadał mu swoją interpretację ${ }^{85}$. O ile

85 Tekst ten doczekał się bardzo wielu komentarzy. W tradycji żydowskiej uchodził za jeden z pięciu najbardziej intrygujących tekstów Tory (obok Rdz 49,6 i 7; Wj 17,9; 37,20 i Pwt 31,16) - por. J. Cook, The Exegesis of the Greek Genesis, s. 113 i 124. Na temat Rdz 4 
niektórzy, opierając się na tekście hebrajskim, uważają, że Pan Bóg kierując się wyłącznie swoim kaprysem, przyjął ofiarę Abla, a nie przyjął ofiary Kaina, i w ten sposób oskarżają Pana Boga, że stał się przez ten „nieracjonalny” wybór niejako przyczyną bratobójstwa, tłumacz grecki przedstawia własną interpretację tego tekstu, nie pozostawiającą wątpliwości, że to sam Kain odpowiadał za to, że Bóg nie przyjął jego ofiary. Dokładną interpretację tekstu hebrajskiego i greckiego można znaleźć w opracowaniu K. Jobes i M. Silvy, w niniejszym opracowaniu chciałam uwypuklić grecką zmianę, która pojawia się najwyraźniej w w. 4,7.

Po ww. 1-2 mówiących o urodzeniu obu braci, Kaina i Abla, w w. 3 zaczyna się historia składania przez nich ofiar. W tekście hebrajskim czytamy, że obaj bracia składali ofiarę Panu, najpierw starszy - Kain, potem Abel. Kain „składał płody roli w ofierze dla Pana” (w. 3), „zaś Abel, również on, składał pierwociny ze swej trzody i ich tłuszczu” (w. 4a). „Pan wejrzał na Abla i na jego ofiarę" (w. 4b), „a na Kaina i na jego ofiarę nie wejrzał”. Wielu komentatorów (a nawet niektóre przekłady) tłumaczą, że „Pan nie chciał patrzeć na ofiarę Kaina” (m.in. Biblia Tysiąclecia), co miałoby być wyrazem Bożego kaprysu. Kain rozzłościł

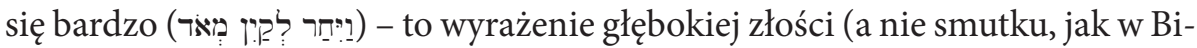
blii Tysiąclecia: „smuciło to Kaina bardzo”) i chodził z ponurą twarzą.

Od w. 6 rozpoczyna się wypowiedź Boga, kluczowa dla interpretacji tego fragmentu, którą grecki tłumacz zrozumiał chyba lepiej niż współcześni komentatorzy.

Tekst hebrajski:

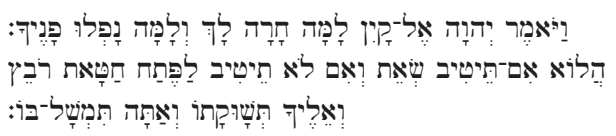

„Rzekł Pan do Kaina: «Dlaczego się złościsz i dlaczego masz ponurą twarz (dosł. opadła Twoja twarz)? Czyż, jeśli czyniłbyś dobrze [nie] podniósłbyś [twarzy], a skoro nie postępujesz dobrze, grzech leży u wrót i na Ciebie czyha? Ale ty możesz nad nim panować»".

w LXX oraz jego porównanie z Tekstem Masoreckim zob. V. Aptowitzer, Kain und Abel in der Agada, den Apokryphen der hellenistischen, christlichen und muhammedanischen Literatur, Leipzig 1922; J. N. Lohr, Righteous Abel, Wisked Cain: Genesis 4:1-16 in the Masoretic Text, the Septuagint, and the New Testament, „Catholic Biblical Quarterly” 71/2009, s. 485-496; por. także: K. Jobes, M. Silva, Interpreting the Septuagint and Other Greek Versions, w: Invitation to the Septuagint, s. 206-215; M. Harl, La Bible d'Alexandrie I: La Genèse, s. 112-115; J. Cook, The Exegesis of the Greek Genesis, s. 113-116. 
Cały kontekst ww. 1-2, a potem 3-5 zasadniczo w tekście greckim jest taki sam. Zmiana pojawia się w w. 4, gdzie zamiast ofiary Abla (w liczbie pojedyn-

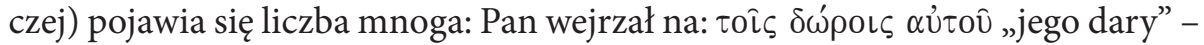
co ukazuje, że Abel dawał nie tylko pierwociny, ale dawał jakby więcej niż było

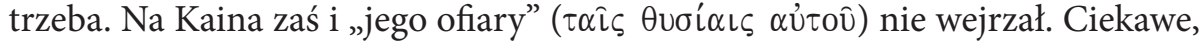

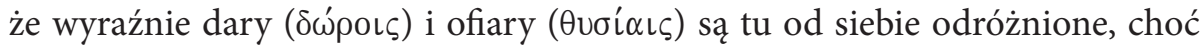
po hebrajsku tłumaczą to samo słowo w tekście hebrajskim) - komentatorzy starożytni przypisywali w tym miejscu greckiemu terminowi także znaczenie zazdrości ${ }^{87}$ - i chodzi z ponurą twarzą.

Kluczowe dla zrozumienia różnicy są ww. 6-7, wypowiedź Boga. W tekście greckim brzmi ona:

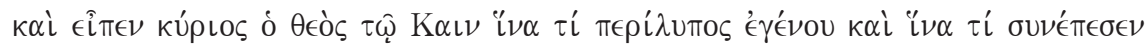

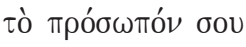

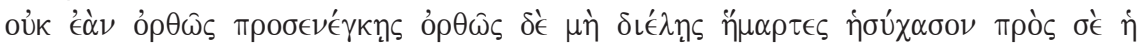

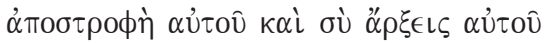

„I rzekł Pan Bóg do Kaina: «Czemu stałeś się rozgoryczony? I czemu opadło Twoje oblicze?

Czyż nie zgrzeszyłeś skoro złożyłbyś ofiarę poprawnie, ale nie podzieliłeś poprawnie? Wycisz się. Jego odwrócenie [o gniewie] jest u ciebie, a ty możesz nad nim [gniewem] panować»".

Sam w. 7 jest w tekście hebrajskim niezrozumiały i niejednokrotnie badacze odwołują się do tekstu greckiego, by objaśnić tekst hebrajski ${ }^{88}$. „Jasne jest, że sam tłumacz grecki miał z nim kłopot, a jego przekład nie może z tego powodu być pomocny w rekonstrukcji hebrajskiego pierwowzoru" ${ }^{89}$. Boryka się z tym trudnym tekstem jak potrafi, na poziomie słów i na poziomie znaczenia - chce wyjaśnić, dlaczego Bóg nie wejrzał na ofiarę, która zgodnie z Prawem Mojżeszowym była dobra. I wyjaśnia to, że Kaina ofiara była dobra, ale była niepoprawnie złożona („nie podzielona poprawnie”). Filon Aleksandryjski, pierwszy komentator greckiej wersji Księgi Rodzaju, doda, że to niepoprawne podzielenie polegało na tym, że Kain najlepszą część z ofiary zachował dla sie-

\footnotetext{
86 M. Harl, La Bible d'Alexandrie I: La Genèse, s. 113.

87 Tamże, s. 113-114.

88 K. Jobes, M. Silva, Interpreting the Septuagint and Other Greek Versions, s. 212.

89 Tamże, s. 212-213.
} 
bie ${ }^{90}$. Być może mamy zatem w LXXRdz pozostałość, w jaki sposób żydowska społeczność interpretowała w starożytności ten niełatwy tekst ${ }^{91}$.

Ostatnia część tego wersetu w LXXRdz także jest trudna ${ }^{92}$. Każdy ze współczesnych przekładów LXX tłumaczy go inaczej:

R. J. V. Hiebert (NETS ${ }^{93}$ : „Be still; his recourse is to you and you will rule over him";

K. Jobes; M. Silva ${ }^{94}$, „Be still: he will return to you, and you will rule over him”;

M. Harl (La Bible d'Alexandrie) $)^{95}$, „Reste tranquille. Que vers toi aille son mouvement et tu le commmanderas".

Czy mowa jest tu o grzechu? O smutku? O ofierze? J. W. Wevers, za tradycją starożytną Filona Aleksandryjskiego ${ }^{96}$, zaproponował, że chodzi o grzech ${ }^{97}$. Inne tradycje starożytne, np. Ireneusz, mówiły, że zaimek aủroû odnosi się tu nie do grzechu, smutku czy zazdrości, ale do Abla ${ }^{98}$, który zbliży się do Kaina, a ten nad nim zapanuje (przez zadanie mu śmierci). W takim rozumieniu Bóg w ten sposób kieruje słowa do Kaina, jakby zapowiadając czyn, który za chwilę nastąpi. Inną propozycję za anonimowym autorem starożytnym proponuje Prokopiusz, który uważa, że to ostatnie zdanie Bóg kieruje nie do Kaina, ale do Abla, mówiąc, że Kain zbliży się do niego, ale on nad nim zapanuje - przez swoją śmierć, jak Chrystus zapanował nad Żydami przez swoją śmierć99.

Mimo objaśnień tekst ten pozostaje nadal trudny. Faktem jest jednak, że tłumacz grecki chciał jakoś wyjaśnić fakt, dlaczego Bóg nie przyjął ofiary Kaina. Nie chcąc zarzucać Bogu kaprysu - ukazał, że ofiara Kaina była dobra, ale niepoprawnie złożona. W jakimś sensie oczyszcza to Boga z kierowanego pod Jego adresem zarzutu o stronniczość, która w konsekwencji miała doprowadzić do bratobójstwa.

90 M. Harl, La Bible d'Alexandrie I: La Genèse, s. 114.

91 K. Jobes, M. Silva, Interpreting the Septuagint and Other Greek Versions, s. 213.

92 Por. na jej temat J. W. Wevers, Notes on the Greek Text of Genesis, s. 55-56.

93 R. J. V. Hiebert, Genesis, w: NETS, s. 8.

94 K. Jobes, M. Silva, Interpreting the Septuagint and Other Greek Versions, s. 212 oraz 213-214 (objaśnienie).

95 M. Harl, La Bible d'Alexandrie I: La Genèse, s. 114.

96 Tamże, s. 115.

97 J. W. Wevers, Notes on the Greek Text of Genesis, s. 56.

98 M. Harl, La Bible d'Alexandrie I: La Genèse, s. 115.

99 Tamże. 
W w. 8 tego tekstu pojawia się także bardzo ważny i znany dodatek LXX, za którym uzupełniają tekst hebrajski niemal wszystkie jego wydania. W tekście hebrajskim bowiem brak słów Kaina do brata Abla. Tekst ten brzmi:

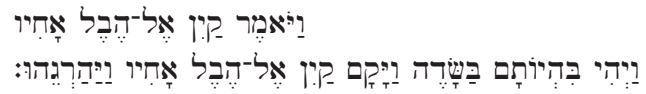

„I rzekł Kain do Abla, swego brata.

A kiedy byli na polu Kain powstał przeciw Ablowi, bratu swemu i zabił go".

Tłumacz grecki przełożył ten tekst wiernie, uzupełniając zarazem brakują-

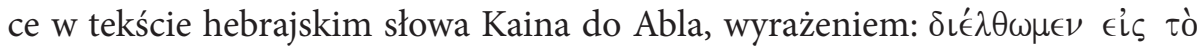
$\pi \in \delta$ íov („Chodźmy na pole”). To wyrażenie znane jest z Pięcioksięgu Samarytańskiego, z syryjskiej Peszitty i Vulgaty ${ }^{100}$, a także uzupełniają go w ten - najbardziej logiczny - sposób współczesne przekłady. Jest to jeden z najbardziej znanych problemów tekstualnych Księgi Rodzaju ${ }^{101}$. Wydaje się, że uzupełnienie to we wszystkich wymienionych wersjach jest wzięte za LXX.

\section{Zmiany dostosowujące tekst do nowego języka i środowiska}

W tekście LXXRdz odnaleźć można jeszcze inne przykłady zmian, które będą związane już z potrzebami czytelników greckich tej Księgi. Zmiany te, uczynione przez tłumacza, dotyczą np. miejsc, które mogły brzmieć w sposób niezrozumiały dla czytelników posługujących się językiem greckim ${ }^{102}$. Typowe dla języka hebrajskiego wyrażenia, które nie były zrozumiałe na gruncie języka greckiego tłumacz niejednokrotnie upraszczał. Najlepszym przykładem może być wyrażenie מוֹת תָמוּת („śmiercią umrzesz”) z Rdz 20,7. Tłumacz przekłada go po prostu jako $\alpha \dot{\pi} 0 \theta \alpha \nu$ ṇ („umrzesz”). Nie czyni kalki z języka hebrajskiego, dla którego taka podwójna konstrukcja była typowa dla języka greckiego zaś byłaby obca. Jednak, co ciekawe, w innym miejscu Rdz, w w. 2,17 to samo hebrajskie wyrażenie jest przełożone tak, jak gdyby było kalką hebrajskiego zwrotu: $\theta \alpha \nu \alpha ́ \tau \omega \dot{\alpha} \pi 0 \theta \alpha \nu \in \hat{\imath} \sigma \theta \in$ („śmiercią umrzesz"). Dlaczego taka niekonsekwencja? Albo słusznym jest pogląd, iż Księgę Rodzaju tłumaczyło wielu tłumaczy, albo, jak uważa K. P. Kowalik, „zmiana wprowadzona w 20,7 mogła być dyktowa-

100 K. Jobes, M. Silva, Interpreting the Septuagint and Other Greek Versions, s. 214.

101 Tamże, s. 214-215.

102 Na ich temat zob. K. P. Kowalik, Wprowadzenie nowych znaczeń dla terminów greckich i eliminacja miejsc niezrozumiałych dla greckojęzycznego czytelnika, w: tenże, Reinterpretacja tekstu o Abrahamie w Rdz 11,27-25,18 w Septuagincie, s. 255-262. 
na chęcią odróżnienia od siebie tych epizodów"103 (sytuacji pierwszych ludzi w raju i później w życiu Abimeleka).

Ciekawa zmiana związana z interpretacją i harmonizacją tekstu, a być może także wynikająca $\mathrm{z}$ niezrozumienia hebrajskiego tekstu i jego sensu, dotyczy także lat życia patriarchów w Rdz 5-11. Mówiąc najkrócej, liczby lat życia różnią się między Tekstem Masoreckim, Septuagintą, a np. Pięcioksięgiem Samarytańskim. Na przykład lata życia Adama w tekście hebrajskim wynoszą 800 lat, a w LXX - 700. Tak jest jeszcze w kilku przypadkach: Set - 807 lat w tekście hebrajskim, a 707 w LXX; Enosz - 815, a w LXX 715.

Jak twierdzą niektórzy (np. M. Rösel), greckie tłumaczenie (zawierające inne lata życia) wynika $\mathrm{z}$ ukierunkowania tłumacza na zmianę daty stworzenia świata. W starożytności były bowiem tendencje, by zliczać lata i ustalać $\mathrm{w}$ ten sposób rok stworzenia ( $\mathrm{z}$ tego powodu rabini określali datę stworzenia świata na rok - odnosząc do naszego kalendarza - 3761 przed Chr.). W Egipcie hellenistycznym także tworzono takie daty. Jak sugeruje M. Rösel tłumacz LXX chciał ukazać w swoim przekładzie LXX, że „w roku 5000 od stworzenia świata wybudowano drugą świątynię"104 i w ten sposób wpisać dzieje narodu żydowskiego we wówczas spisywane przez Manetona dzieje egipskie (Maneton podzielił dzieje Egiptu na XXX dynastii, ok. 3000 lat) ${ }^{105}$. Może między jedną a drugą społecznością w Aleksandrii prowadzono dysputy nad rachubą czasu, i efekt tego mamy w zmianie lat życia w greckim przekładzie. To jedna z prób objaśnienia tej różnicy w długości lat życia bohaterów Rdz.

Jeszcze inne zmiany dostosowujące do nowego środowiska i języka będą dotyczyły np. unikania antropomorfizmów w mówieniu o Bogu, tak by uniknąć kojarzenia Jedynego Boga Izraelitów z bogami pogańskimi ${ }^{106}$.

Wśród zmian tego typu można znaleźć także te, które pogłębiały znaczenie tekstu biblijnego. Wśród takich K. P. Kowalik wylicza teksty dotyczące Abra-

103 Na ich temat zob. tamże, s. 256.

104 M. Rösel, übersetzung als Vollendung der Auslegung. Studien zur Genesis-Septuaginta, s. 104-107 oraz tenże, The Text-Critical Value of Septuagint-Genesis, s. 67.

105 Tamże.

106 Na ten temat wraz z przykładami zob.: J. Cook, The Exegesis of the Greek Genesis, s. 116-119; K. P. Kowalik, Antypoliteistyczne tendencje tekstu, w: tenże, Reinterpretacja tekstu o Abrahamie w Rdz 11,27-25,18 w Septuagincie, s. 430-450. O Bożym imieniu w LXXRdz zob. także: tenże, Określenia Boga w Biblii Greckiej, w: tamże, s. 450-498; oraz J. Skinner, The Divine Names in Genesis: III Recensions of the Septuagint, „The Expositor” 8 (1913)5, s. 494-514 ; M. Rösel, Die Übersetzung der Gottesnamen in der Genesis-Septuaginta, w: Ernten, was man sät, red. D. R. Daniels, Neukirchen-Vluyn 1991, s. 357-377. 
hama ${ }^{107}$, np. w tekście o powołaniu z rozdz. 12, w którym LXXRdz podkreśla opuszczenie trzech rzeczywistości: ziemi, krewnych i domu ojca, wszystkiego, co bliskie człowiekowi; w szczególnym podkreśleniu posłuszeństwa Abrahama wobec Bożych nakazów; kiedy Abraham ukazany jest jako pośrednik między Bogiem a narodami; i inne.

W przekładzie LXX Rdz, tak jak i w innych księgach LXX, spotkamy także, choć nieliczne, ale jednak, adaptacje do nowych warunków polityczno-społecznych ${ }^{108}$. Wśród nich dość wspomnieć te najbardziej wyraźne: na pierwszy plan wysuwają się teksty, w których wyraźnie widać łagodzenie wymowy antyegipskiej, zwłaszcza w tekstach dotyczących Sary na dworze faraona (Rdz 12,15-16) ${ }^{109}$, gdzie wersja LXX nieco inaczej, bardziej osobowo przedstawia urzędników faraona. Takie zmiany mogły być tym bardziej zrozumiałe, że przecież LXX powstała w konkretnym środowisku aleksandryjskim, w którym wystąpienia o charakterze politycznym mogły być źle odebrane ${ }^{110}$.

\section{Zakończenie}

Można mnożyć przykłady jeszcze innych interpretacji i zmian, analizując poszczególne teksty LXXRdz ${ }^{111}$. Te omówione w artykule mogą być obrazem dylematów tłumacza i obrazem jego interpretacji Księgi Rodzaju w jej greckim przekładzie. Z pewnością znaczący jest fakt, że zmian nie ma tak wiele, jak $\mathrm{w}$ innych Księgach LXX. Jak zostało podkreślone, zapewne wynikało to $\mathrm{z}$ faktu, że Księga Rodzaju była tak ważna księgą w tradycji, pierwszą księgą ST i dlatego dołożono wszelkich starań, by ją przełożyć jak najdokładniej. Na przykładzie Księgi Rodzaju jednocześnie bardzo wyraźnie zarysowuje się paradoks, z którym musieli zmierzyć się wszyscy tłumacze LXX: chcieli oni oddać tekst najbardziej wierny oryginałowi hebrajskiemu, a także chcieli zarazem oddać

107 K. P. Kowalik, Pogłębienie znaczenia tekstu biblijnego, w: tenże, Reinterpretacja tekstu o Abrahamie w Rdz 11,27-25,18 w Septuagincie, s. 265-319.

108 Na temat tego typu zmian zob.: K. P. Kowalik, Aspekty przekładu uwarunkowane rzeczywistościa diaspory aleksandryjskiej, w: tenże, Reinterpretacja tekstu o Abrahamie w Rdz 11,27-25,18 w Septuagincie, s. 393-402.

109 Tamże, s. 393-395.

110 Z podobnym przypadkiem mamy do czynienia w Księdze Hioba, gdzie wyraźny tekst antymonarchiczny, został zamieniony, ze względu na swoiście rozumianą poprawność polityczną, na tekst pochwały książąt (Hi 34,17-19), por. B. Strzałkowska, Mowy Elihu i ich reinterpretacja w Biblii Greckiej, s. 328-336 (zwł. 334-336) oraz 620-621.

111 Więcej przykładów zob.np. R. J. V. Hiebert, The Hermeneutics of Translation in the Septuagint of Genesis, s. 85-103. 
tekst najwierniejszy swojemu rozumieniu tego tekstu i językowi greckiemu, na który przekładali.

Ponieważ nie ma w greckiej Księdze Rodzaju równości: z jednej strony przekład jest bardzo dosłowny i wierny hebrajskiemu pierwowzorowi, z drugiej zaś w niektórych miejscach swobodniejszy, pojawiły się w tradycji badań nad LXXRdz pomysły, że tłumaczyło ją dwóch (lub więcej) tłumaczy. Jedna z tych teorii mówi, że pierwszy z nich miał przełożyć rozdz. 1-25, drugi, rozdziały 26-50 - tę teorię przedstawiano w latach 30 . i jest to ciekawy, trochę zapomniany, przyczynek do historii badań nad tekstem LXX Rdz ${ }^{112}$. Według tych badaczy, różnice stylistyczne obecne w tych dwóch częściach księgi, pozwalają na taką właśnie radykalną interpretację dotyczących tłumaczenia. Obecnie jednak niewielu badaczy popiera tę koncepcję, ukazując omówione różnice raczej chęcią posiadania przekładu wiernego, a jednocześnie dostosowanego do potrzeb wspólnoty, do której przekład ten był kierowany. Faktem jest, że w większość zmian wydaje się dziełem samego tłumacza, który dostosowywał tekst hebrajski i go harmonizował. Nie wydaje się, by przyczyną tego miało być inne Vorlage tego tekstu ${ }^{113}$.

Bardziej prawdopodobne jest, iż te zmiany, harmonizacje i doprecyzowania tekstu są dla nas bardziej świadectwem rozumienia i interpretacji hebrajskiego tekstu. To rzuca nowe światło na znaczenie przekładu LXX - jako źródła wiedzy o interpretacji Pisma Świętego i o teologii wspólnoty żydowskiej okresu hellenistycznego (a nie tylko jako źródła dla krytyki tekstualnej hebrajskiego pierwowzoru $)^{114}$. Charakterystyka tego przekładu, wraz z problemami tłumacza, błędami, jakie popełnił, i zmianami, jakich dokonał, może stanowić odniesienie dla wszystkich pozostałych ksiąg Biblii Greckiej. W końcu Księga Rodzaju, jako pierwsza Księga, sam początek Tory, pozostaje, czy to w tradycji hebrajskiej, czy greckiej, częścią najważniejszej spuścizny narodu izraelskiego do dziś, jako programowa Księga Starego Testamentu, „Księga Początków”, zgodnie z jej greckim tytułem.

112 Por. O. J. Baab, The Theory of Two Translators for the Greek Genesis, s. 239-243.

113 Nie jest to przedmiotem zainteresowania niniejszego artykułu. O Vorlage LXXRdz i innych ksiąg (m.in. Księgi Wyjścia) zob. m.in. A. Aejmelaeus, What Can We Know About the Hebrew Vorlage of the Septuagint?, w: taże, On the Trail of the Septuagint Translators. Collected Essays, Kampen 1993, s. 77-115.

114 M. Rösel, The Text-Critical Value of Septuagint-Genesis, s. 69-70; por. także J. Cook, The Septuagint of Genesis: Text and/or Interpretation?, s. 328-329. 


\section{Summary}

The article focuses on the presentation of the oldest known translation of the Book of Genesis, that can be found in the Greek Bible - the Septuagint. Starting from the history of the translation, through text witnesses and manuscripts of the Greek text of the Book of Genesis, it describes the nature of this translation: on the one hand very accurate and faithful - even sometimes slavishly subservient to the Hebrew text, on the other hand full of different types of changes, characteristic for the LXX translation in general. These changes, ranging from the title of the Book, in fact show the directions of the interpretation of the Book of Genesis in a time when the canon was still in statu fieri. It is even more important as the Book of Genesis was - in all probability - the first Hebrew book translated into Greek. 